\title{
Development of the Murine Periodontium. II. Role of the Epithelial Root Sheath in Formation of the Periodontal Attachment
}

\author{
R. Lamont MacNeil* and Huw F. Thomas ${ }^{\dagger}$
}

EXPERIMENTAL MANIPULATION OF THE DEVELOPING murine tooth germ has provided evidence that basement membrane components on the forming root surface are involved in early periodontal attachment formation. The purpose of this investigation was to determine the role of epithelial root sheath (ERS) cells in murine cementogenesis and periodontal ligament formation using tissue separation and recombination techniques. Root dentin specimens, with and without root-associated basement membrane components ( $\mathrm{D}+\mathrm{RBM}$ or $\mathrm{D}-\mathrm{RBM}$ ), were recombined with dental sac in the presence or absence of ERS. Recombinations were cultured for 2 weeks, harvested, and examined by light, electron, and immunofluorescence microscopy. Mineralized tissue formed in all tissue recombinations. However, when ERS was included in recombinations between $\mathrm{D}+\mathrm{RBM}$ and dental sac, $25 \%$ of recombinations formed a periodontal ligament with fibrous attachment of the root specimen to adjacent bone. These results support the hypothesis that root and periodontal ligament formation is influenced by epithelio-mesenchymal interactions and further support a key role for ERS in these processes. $J$ Periodontol 1993;64:285-291.

Key Words: Cementum; periodontal ligament; basement membrane; periodontal attachment.

While current opinion holds that the tissues which comprise the periodontal attachment (i.e., cementum, periodontal ligament, and alveolar bone) originate from dental sac ectomesenchyme, relatively little is known about the inductive events which regulate the differentiation and maturation of these tissues. This information is essential to a comprehensive understanding of the mechanisms which underlie normal tooth root formation. In addition, the cellular and extracellular conditions which accompany early development of the periodontal attachment may resemble the microenvironmental conditions required for successful regeneration of the postdevelopmental periodontium. Hence, elucidation of the tissue interactions which govern tooth root and periodontal attachment formation could yield information of therapeutic benefit.

Our understanding of the events which occur between initiation and completion of root and periodontal ligament (PDL) development is based largely on studies in which

${ }^{*}$ Department of Periodontics/Prevention and Geriatrics, School of Dentistry, University of Michigan, Ann Arbor, MI.

${ }^{\dagger}$ Formerly, Department of Pediatric Dentistry, University of Connecticut Health Center; currently, University of Texas Health Science Center, San Antonio, TX. developing murine (mouse) molar tooth germs have been histologically examined ${ }^{1-6}$ or experimentally manipulated. ${ }^{7-10}$ In early studies, radiolabeled tooth germs were transplanted to extraoral sites in an effort to determine the origin of various periodontal tissues; PDL and alveolar bone tissues were reported to originate from the labeled cells of the investing layer of dental sac. ${ }^{7,8}$ Investigations in which tooth germ components (i.e., enamel organ, epithelial root sheath [ERS], dental papilla, and dental sac) were first separated and then heterotypically recombined before transplantation have also reported formation of a functional periodontal attachment. 9,10 However, in these latter studies, PDL development occurred only when odontogenic epithelium was knowingly or inadvertently included with the recombined tissues. These latter findings provide indirect evidence that PDL development requires interaction between root sheath epithelium and tissues of mesenchymal origin (i.e., dental sac, dentin). Epitheliomesenchymal interactions have been well documented during coronal tooth development ${ }^{11}$ and it is now known that root odontoblast differentiation is dependent upon interaction between dental papilla and ERS cells. ${ }^{12,13}$ Evidence that epithelium may be involved in periodontal attachment formation is further supported by tooth reimplantation studies which cor- 
relate the successful reformation of a functional periodontal ligament with the presence of epithelial cells within the reimplanted tissues. ${ }^{14-16}$

We have recently reported the formation of cementumlike mineralized tissue in tissue recombination experiments involving murine dentin and dental sac tissues. ${ }^{17}$ In the presence of an intervening basement membrane, dental sac cells formed an adherent acellular mineralized tissue on the dentin surface; periodontal ligament formation was not observed. Since epithelial root sheath cells were not included in these recombinations, the following study was initiated to investigate a possible role for this epithelium in periodontal development.

\section{MATERIALS AND METHODS}

The protocol for this study was reviewed and approved by The University of Connecticut Animal Experimentation Committee.

\section{Isolation and Preparation of Tissues}

Root dentin fragments (approximately $1.0 \times 1.5 \mathrm{~mm}$.) were obtained from day- 8 postnatal CD-1 mice. ${ }^{\ddagger}$ At this stage of development, cementum had not yet formed ${ }^{18}$ and enough root structure existed for manipulation. Dentin specimens were processed in one of two ways. Some specimens were incubated in $1.0 \%$ trypsin $^{\S}(1: 250)$ for 30 minutes at $4.0^{\circ} \mathrm{C}$ to remove both cells and basement membrane ${ }^{19}$ (i.e., D $\mathrm{BM}$ ); others were incubated in $0.1 \mathrm{M}$ EDTA (ethylenediaminetetraacetic acid) in $\mathrm{Ca}^{++}-\mathrm{Mg}^{++}$-free $\mathrm{HBSS}^{\S}$ (Hank's balanced salt solution) for 15 minutes at $37^{\circ} \mathrm{C}$ to remove cells and to preserve the associated basement membrane ${ }^{19}$ (i.e., D + BM). Absence or presence of basement membrane components was confirmed by immunohistochemistry (see below). Absence of viable cells was ensured by freeze-thawing all specimens in distilled water $(\times 3)$ and confirmed by test culturing random specimens on $0.4 \%$ agar-supplemented minimum essential medium (MEM). ${ }^{\S}$

Dental sac (DS) and ERS were obtained from day-6 postnatal CD-1 mice. Mandibular first molar tooth germs were removed and placed in $1.0 \%$ trypsin for 2 hours at $4.0^{\circ} \mathrm{C}^{21}$ Isolation of dental sac tissue and ERS were isolated following the techniques of Thomas and Kollar. ${ }^{13}$ Although the root sheath could be removed intact, more often some fragmentation occurred and horse-shoe shaped fragments were obtained.

\section{Tissue Recombination and Grafting}

The experimental groups consisted of recombinations of ERS fragments and dental sac with either 1) root dentin devoid of root-associated basement membrane (group A, $\mathrm{n}$ $=16$ ), or 2) dentin with root-associated basement membrane (RBM) preserved (group $\mathrm{B}, \mathrm{n}=16$ ). Isolated tissues were recombined to duplicate their in vivo spatial orienta-

${ }^{\ddagger}$ Charles River Labs, Cambridge, MA

${ }^{\S}$ Sigma Chemical Co., St. Louis, MO. tion; two to three isolated fragments of ERS were placed on the convex, periodontal aspect of the root dentin specimen followed by addition of dental sac tissue. Tissues were recombined on $0.4 \%$ agar-supplemented $\alpha$-MEM with $10 \%$ fetal bovine serum (FRBS), $1.0 \%$ glutamine, and $0.1 \%$ gentamycin. Recombinations were incubated overnight in a humidified chamber with $5 \% \mathrm{CO}_{2}$ in air at $37^{\circ} \mathrm{C}$ to allow the tissues to adhere. The next day, recombinations were grafted into the anterior chamber of the eye of homologous adult male mice following established protocols. ${ }^{13}$ Animals were anesthetized with a combination of ketamine hydrochloride" $(100 \mathrm{mg} / \mathrm{ml}) 100 \mathrm{mg} / \mathrm{kg}$ body weight and xylazine $(100 \mathrm{mg} / \mathrm{ml}) 11 \mathrm{mg} / \mathrm{kg}$ body weight. Care was taken to avoid excessive trauma during the grafting procedure; any grafting procedure that produced bleeding was excluded. One graft was placed per animal.

A total of 32 group A (D-RBM + ERS + DS) and group $\mathrm{B}(\mathrm{D}+\mathrm{RBM}+\mathrm{ERS}+\mathrm{DS})$ recombinations were grafted. Control grafts $(n=5)$ consisted of dental sac tissue alone. Grafts were harvested after 2 weeks. Animals were sacrificed by cervical dislocation and the eye removed and processed for either light, immunofluorescence, or electron microscopy.

\section{Light Microscopy}

Specimens were fixed in $10 \%$ neutral buffered formalin, demineralized in formic acid/citric acid, dehydrated, cleared in xylene, and embedded in paraffin. Serial $7 \mu \mathrm{m}$ sections were cut, stained with hematoxylin and Biebrich scarlet, and examined by light microscope. ( $n=12$ /group).

\section{Immunohistochemistry}

Root dentin fragments and ocular graft specimens were fixed in $95 \% \mathrm{ETOH}$ and embedded in paraffin. ${ }^{23}$ Sections $7 \mu \mathrm{m}$ thick were cut, demineralized in $0.5 \mathrm{M}$ EDTA $(\mathrm{pH} 7.4)$ for 30 minutes, deparaffinized, and rinsed thoroughly in phosphate buffered saline (PBS; $0.02 \mathrm{M}, \mathrm{pH} 7.3$ ). Sections were rinsed in PBS containing $1 \%$ bovine serum albumin; incubated with antibodies to keratin, laminin, or alkaline phosphatase (as appropriate) for 30 minutes at $37^{\circ} \mathrm{C}$; and washed for 30 minutes in PBS at room temperature. Sections were incubated with fluorescein (FITC)-labeled IgG (as appropriate) for 30 minutes at $37^{\circ} \mathrm{C}$. Finally sections were washed for 30 minutes with PBS and coverslipped in glycerol-PBS (1:9) containing $0.1 \%$ paraphenylenediamine to reduce photobleaching, ${ }^{24}$ sections were examined in a photomicroscope equipped with epifluorescence.

Antisera were used at the following dilutions in PBS: rabbit antilaminin (gift from Dr. M. Tanzer, University of Connecticut) at $1 / 50$, rabbit anti-keratin" at $1 / 100$, and rabbit anti-alkaline phosphatase (gift from Dr. R. Majeska, Mt. Sinai School of Medicine, NY) at 1/100. FITC-labeled sec-

"Ketaset, Alveo Co., Fort Dodge, IA.

"Dako Corp., Santa Barbara, CA. 
Table 1. Summary of Tissue Recombinations Involving Dentin (D), Root Basement Membrane (RBM), Dental Sac (DS), and Epithelial Root Sheath (ERS)

\begin{tabular}{|c|c|c|c|c|c|c|c|}
\hline \multirow[b]{3}{*}{ Group } & \multirow[b]{3}{*}{ Tissues Used } & \multirow[b]{3}{*}{$\mathrm{n}$} & \multirow{2}{*}{\multicolumn{2}{|c|}{$\begin{array}{l}\text { Immuno- } \\
\text { fluorescence }\end{array}$}} & \multicolumn{2}{|c|}{ Mineralization } & \multirow{3}{*}{$\begin{array}{c}\text { PDL } \\
\text { Formation }\end{array}$} \\
\hline & & & & & Non & & \\
\hline & & & Keratin & $\mathrm{AP}$ & adherent & Adherent & \\
\hline \multirow{2}{*}{$\begin{array}{c}\text { Control } \\
\text { A }\end{array}$} & DS & 5 & - & + & $\mathrm{n} / \mathrm{a}$ & $\mathrm{n} / \mathrm{a}$ & $\mathrm{n} / \dot{\mathrm{a}}$ \\
\hline & $\begin{array}{c}\text { DS, D, } \\
\text { ERS }\end{array}$ & 16 & + & + & $\begin{array}{c}1 / 12 \\
(8 \%)\end{array}$ & $\begin{array}{c}11 / 12 \\
(92 \%)\end{array}$ & - \\
\hline B & $\begin{array}{l}\text { DS, D, } \\
\text { RBM, and } \\
\text { ERS }\end{array}$ & 16 & + & + & $\begin{array}{r}0 / 12 \\
(0 \%)\end{array}$ & $\begin{array}{c}12 / 12 \\
(100 \%)\end{array}$ & $\begin{array}{c}3 / 12 \\
(25 \%)\end{array}$ \\
\hline
\end{tabular}

ond goat anti-rabbit antibody* was diluted in PBS at 1/100. In controls, the first antisera were replaced with normal rabbit serum.

\section{Transmission Electron Microscopy}

Specimens from both experimental groups were fixed in $2.0 \%$ glutaraldehyde in $0.1 \mathrm{M}$ sodium cacodylate buffer (pH:7.2), post-fixed in $2.0 \%$ osmium tetroxide, dehydrated in a graded ethanol series, and embedded in Epon. Thin sections $(60$ to $80 \mathrm{~nm}$ ) were cut, mounted on formvarcoated grids, stained with uranyl acetate and lead citrate, and examined on a Philips 410LS or Jeol 100CX electron microscope. $(\mathrm{n}=2$ /group).

\section{RESULTS}

\section{Tissue Recombinations}

Results are summarized in Table 1. Control grafts containing dental sac formed a bone-like mineralized tissue. In 11 of $12(92 \%)$ group A recombinations (D-RBM + ERS + DS), a mineralized tissue resembling bone formed on the dentin surface (Fig. 1). A distinct metachromatic line demarkated the junction of dentin and adhering mineral; an acellular mineralized material was evident immediately adjacent to this line.

A similar histologic result was seen in 9 of $12(75 \%)$ group $B$ recombinations (D+BM + ERS + DS). A predominately acellular mineralized material was deposited on and adhered to the root dentin surface (Fig. 2); mineral thickness varied from a thin layer in some specimens to a relatively thick deposition of mineralized tissue. In the remaining $25 \%$ of Group B recombinations, an organized structure resembling a periodontal ligament formed peripheral to the dentin-adherent mineralized tissue (Fig. 3). PDL-like fibers could be observed radiating from the dentin surface with apparent insertion into the newly-formed surface layer; these Sharpey-like fibers spanned in an organized fashion from the dentin surface to insert into a zone of surrounding bone. Numerous cells were found interspersed within the matrix

*Miles Scientific, Naperville, IL.

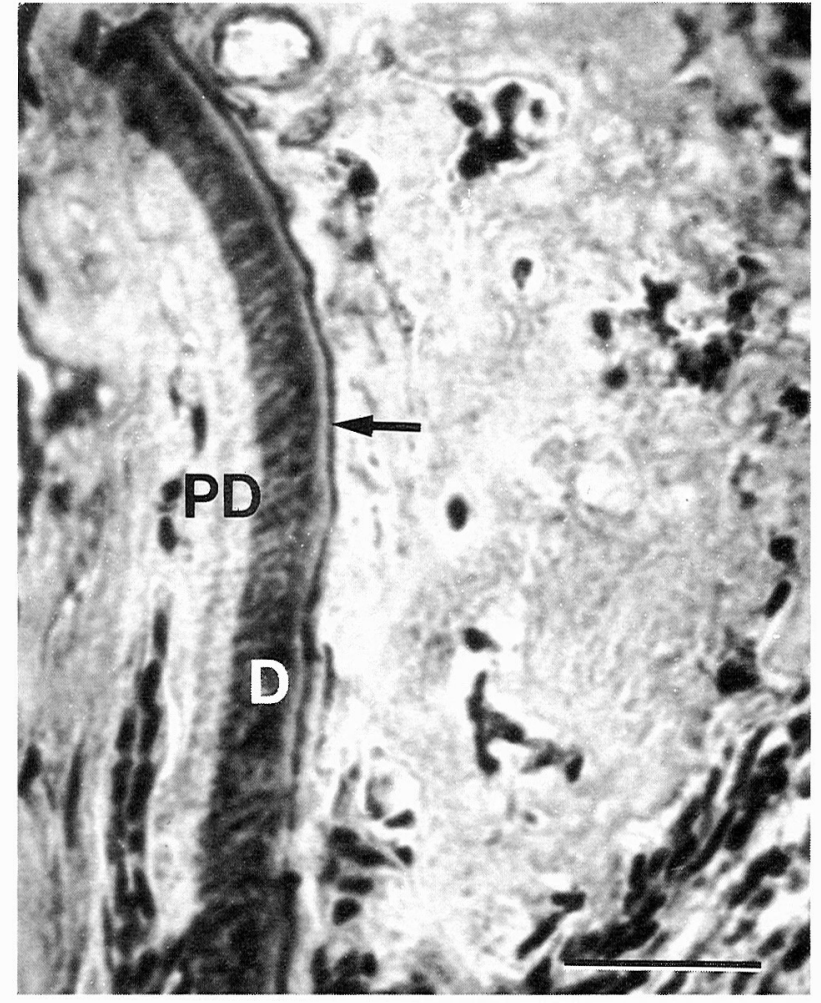

Figure 1. Light micrograph (LM) of a group A specimen with mineralized tissue fused to both the outer (cemental) aspect of dentin $(D)$ and the predentin (PD) surface. A dark line (arrow) delineates the junction of mineral to the cemental surface of the root dentin specimen (bar $=100$ $\mu \mathrm{m})$.

of this fibrous tissue. In total, these specimens resembled a developing root with cementum, periodontal ligament, and alveolar bone components.

\section{Immunohistochemistry}

Specimens from both experimental groups demonstrated specific staining for cytokeratins confirming successful inclusion of ERS (Fig. 4). Specimens from both groups also demonstrated positive immunofluorescence for alkaline phosphatase (figures not shown).

\section{Transmission Electron Microscopy}

Ultrastructural analysis of the dentin-bone interface of group A specimens revealed a layer of darkly-staining cells which lined the dentin surface (Fig. 5). This layer varied in thickness from one to two cells; a one-cell layer structure in parallel orientation to the dentin surface is seen in Figure 5. These darkly-staining cells were characterized by a high nucleus-to-cytoplasm ratio, darkly-staining nuclei, and abundant rough endoplasmic reticulum. In general, this layer of cells appeared more fibroblastic than epithelial: cells tended to be bipolar, desmosomes were only infrequently seen, and keratin granules were not evident. Two zones were identified between the cell layer and the dentin 


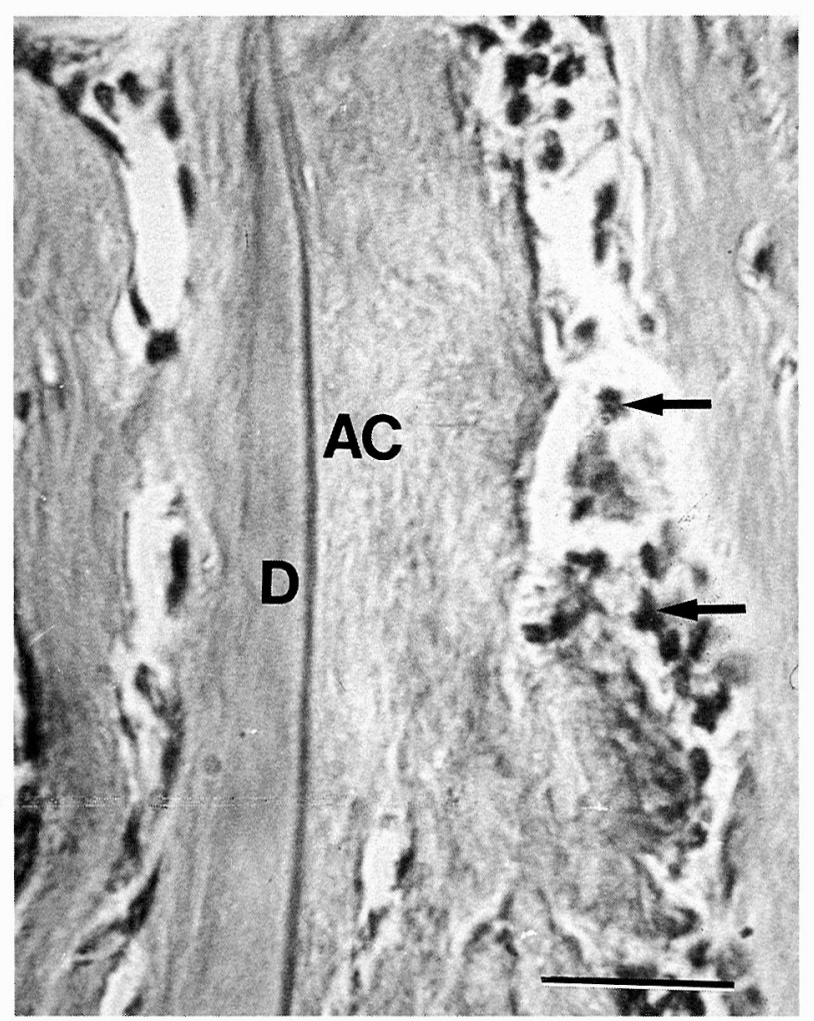

Figure 2. LM of a group B specimen demonstrating an acellular mineralized material $(\boldsymbol{A C})$ adhering to dentin $(\boldsymbol{D})$. Cells (arrows) are seen peripheral to the mineralized tissue (bar $=100 \mu \mathrm{m})$.

surface: 1) a dentin-associated acellular, mineralized zone, and 2) a cell-associated collagenous zone. At the interface of these two zones, collagen fibrils were observed oriented parallel to the root surface. Bone-like tissue was consistently found external to the lining cells.

Examination of ultrathin sections of both group B specimens (D + BM + ERS + DS) revealed histological evidence of periodontal ligament formation (Figs. 6A, 6B, and 6C). In all cases, an adherent layer of mineralized tissue covered the dentin surface; this tissue varied in thickness and cellularity along the length of the dentin specimens (Fig. 6A). In some areas, the adherent mineral was cellular while in other areas it was predominantly acellular but lined peripherally by darkly-staining cells similar to those described in group A specimens. When the latter situation occurred, the lining cells typically presented as a two-cell layer structure separated from the mineralization front by an fibrillar collagenous matrix (Fig.6B). Loss of cellular contact and exaggerated intercellular spacing between cells was frequently observed; dilated cytoplasmic organelles and occasional myelin figures provided further evidence of cellular degeneration (Fig. 6B). Along the length of the dentin specimen, organized collagen fibrils originating from surrounding tissue coursed between the lining cells to insert into the collagenous zone bordering the mineralization front (Fig. $6 \mathrm{C})$.

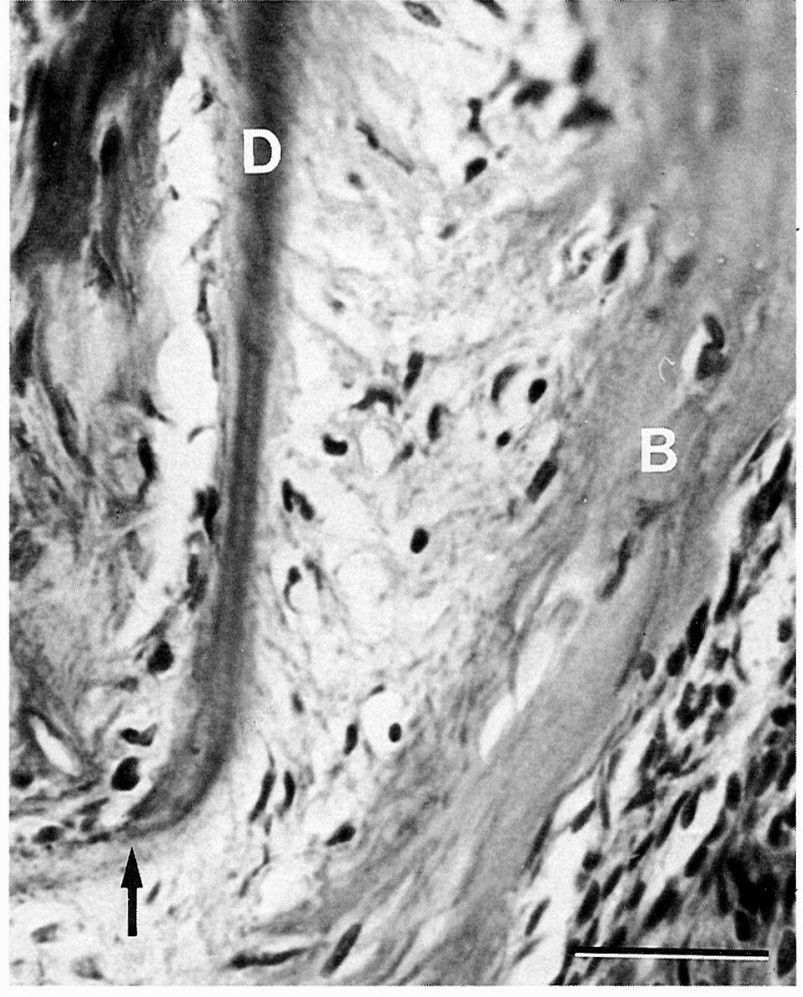

Figure 3. LM of a group B specimen in which a PDL-like structure has developed. Collagenous fibers span from peripheral bone $(\boldsymbol{B})$ to insert into the dentin $(D)$ surface. The apical area of the dentin specimen (arrow) appears to be undergoing elongation or growth (bar $=100 \mu \mathrm{m}$ ).

\section{DISCUSSION}

Studies in developmental biology have established that epithelial-mesenchymal interactions mediate the development of many cells and tissues in the vertebrate body; ${ }^{22}$ these tissues include enamel, dentin, cartilage, and bone. Substantial evidence exists to suggest that epithelial-mesenchymal interactions are also necessary for formation and maintenance of the specialized multi-tissue structure known as the periodontal ligament. For example, PDL formation has been reported in tissue recombination experiments involving odontogenic epithelium. ${ }^{9,10}$ However, the role which epithelium plays in root and periodontal attachment formation has remained a mystery due largely to difficulties in precisely controlling epithelial inclusion or exclusion in these experiments. This present study is the first report of PDL formation in tissue recombinations in which epithelium inclusion was controlled by prior removal and subsequent recombination.

Periodontal attachment formation has also been observed in studies utilizing tooth reimplantation techniques. ${ }^{14-16}$ When extracted monkey incisor roots were combined with dental sac tissue before reimplantation, Andreason and Kristerson ${ }^{15}$ reported cementum formation only in areas where odontogenic epithelial cells were preserved within dental sac. Lindskog et al. ${ }^{16}$ have reported reparative cementum formation in reimplantations where explants of enamel organ epithelium were placed in experimental root cavities; these 


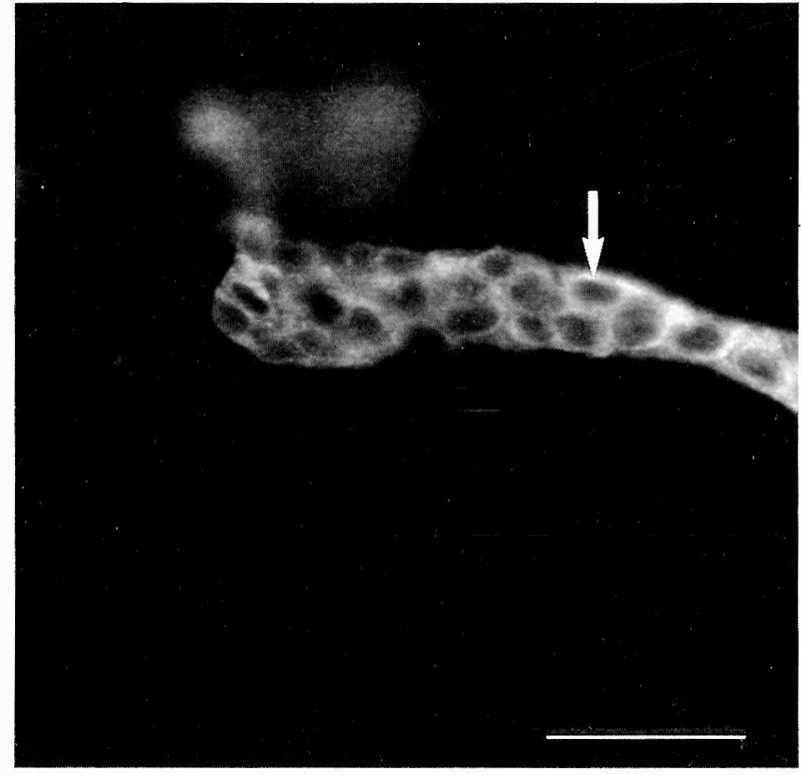

Figure 4. A group A specimen after incubation with antiserum to keratin. The epithelial root sheath is preserved in some areas as two-cell layer structure $($ arrow) $($ bar $=100 \mu \mathrm{m})$.

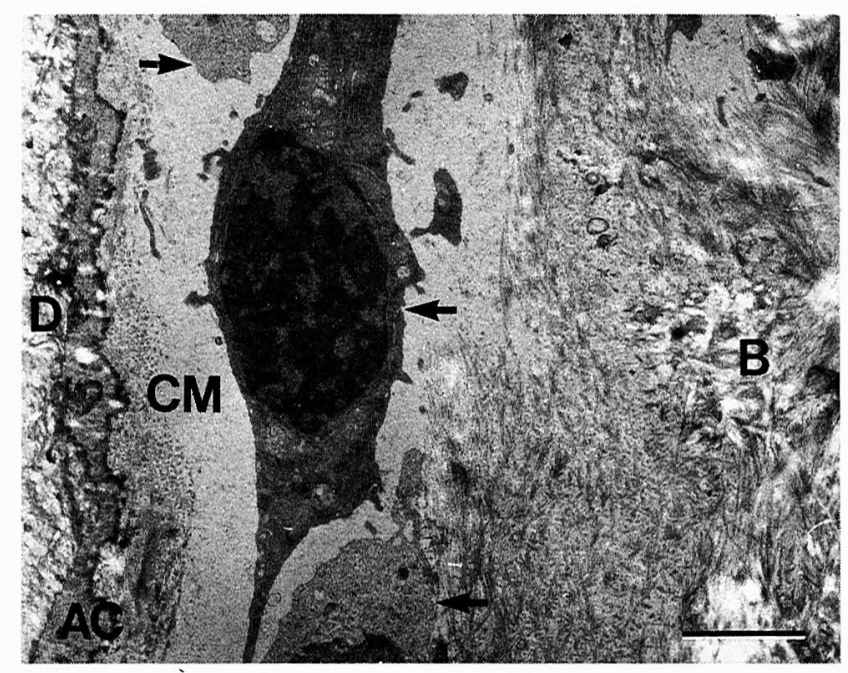

Figure 5. Transmission electron micrograph of a group A specimen. A darkly-staining cell with a large nucleus lines the dentin surface (D). This cell is one in a linear series of cells (arrows) forming a cell layer along the mineralization front. Two zones are seen between the cell layer and dentin: 1) a cell-associated zone of collagen-rich extracellular matrix (CM), and 2) a dentin-associated zone of acellular mineralized tissue (AC). Bone formation $(\boldsymbol{B})$ is seen peripherally $($ bar $=2 \mu \mathrm{m})$.

findings have been interpreted as evidence for a physiologic role for odontogenic epithelium (i.e., epithelial rests of Malassez) in maintaining the periodontal ligament space. Earlier investigations by Löe and Waerhaug ${ }^{14}$ demonstrated that preservation of this epithelial network within the PDL of avulsed teeth was essential in preventing dento-alveolar ankylosis upon subsequent tooth reimplantation.

Our findings suggest that periodontal attachment formation is dependent upon the presence of both epithelium

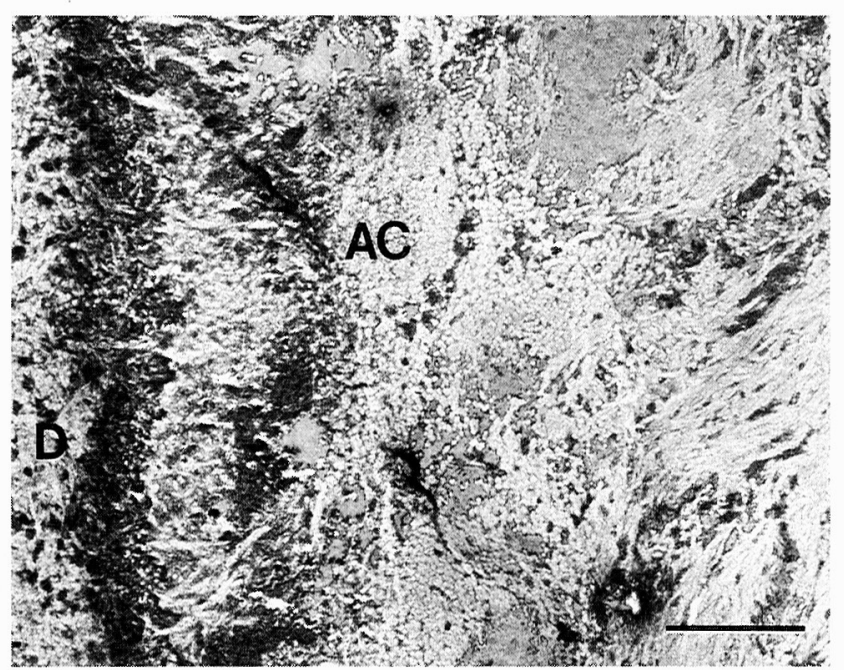

Figure 6A. TEM of a group B specimen. An irregularily-arranged, acellular mineralized material $(\boldsymbol{A C})$ is fused to dentin $(\boldsymbol{D})(\mathrm{bar}=2 \mu \mathrm{m})$.

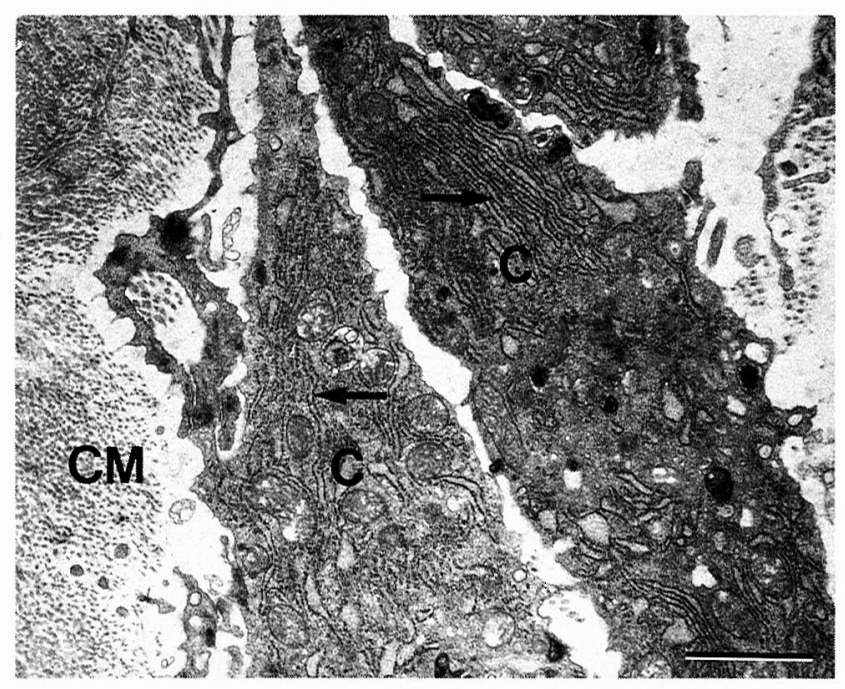

Figure 6B. TEM of the same group B specimen. A double layer of darklystaining cells $(C)$ lies peripheral to the mineralized zone seen in Fig. $6 A$. Cells are separated from mineral front by a densely-arranged collagenous matrix (CM). These cells have abundant rough endoplasmic reticulum (arrows). Numerous dilated cytoplasmic organelles and vacuoles suggest some level of cellular degeneration (bar $=2 \mu \mathrm{m}$ ).

and root-associated basement membrane components. Using similar techniques, we have previously reported that ERSderived basement membrane is required for initiation of mineralized tissue formation on the root dentin surface; this process shared many of the characteristics of early cementogenesis. ${ }^{17}$ In this study, the additional inclusion of epithelial root sheath in recombinations of dentin and dental sac appears to satisfy the biologic requirements for complete periodontal attachment formation. Therefore, we suggest that the epithelial root sheath cells act permissively on undifferentiated dental sac during periodontal ligament induction.

The cellular and molecular mechanisms by which epi- 


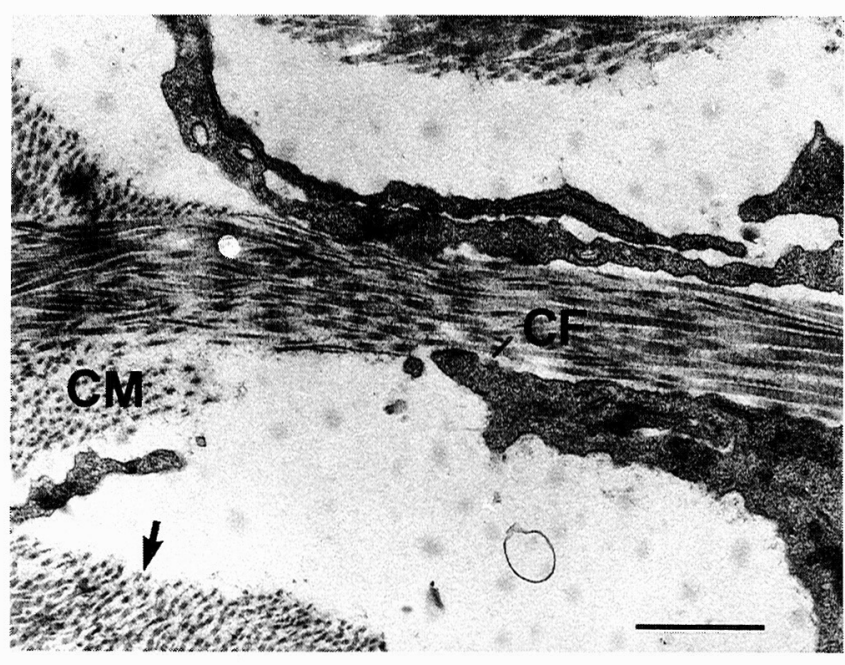

Figure $6 C$. TEM of the same group B specimen. An organized bundle of collagen fibrils $(\boldsymbol{C F})$ courses through the layer of cells described in Figure $6 B$. The fibrils insert into the collagenous matrix $(\mathbf{C M})$ which separates these cells from the mineral front. Collagen fibrils are seen in crosssection (arrow) $($ bar $=1 \mu \mathrm{m})$.

thelio-mesenchymal interactions occur are currently unknown and continue to be the subject of considerable research. ${ }^{22}$ A number of hypotheses have been forwarded to explain how epithelium may regulate the differentiation of neighboring mesenchymal cells. Of the three possible mechanisms of epithelial-mesenchymal interaction (i.e., 1) direct contact of epithelial and mesenchymal cells across a perforated basement membrane; 2) short-range (20 to 40 $\mu \mathrm{m})$ interactions of mesenchymal cells with epithelial basement membrane; or 3) response of mesenchymal cells to a product(s) produced by epithelial cells and diffusing into the mesenchyme), the most well-documented are matrixmediated interactions. ${ }^{23}$ Epithelial cells have been shown to chemically alter the extracellular matrix shared with mesenchymal cells in coculture. ${ }^{24,25}$ Conceivably, the ERS may synthesize molecules similar to enamelin or amelogenin proteins ${ }^{26,27}$ which may in turn mediate inductive changes in neighboring undifferentiated cells via membrane receptor-mediated pathways. ${ }^{28}$ The ERS might also regulate mesenchymal differentiation indirectly through timed alteration of its associated basement membrane; this process may be similar to the composition changes observed in the basement membrane which separates differentiating ameloblasts and odontoblasts during early crown development. ${ }^{29,30}$

In order to test this last hypothesis, this study was designed to compare two experimental groups which differed solely in the retention or absence of root basement membrane. The absence of PDL formation in group A recombinations, where basement membrane was first removed, indirectly suggests that the native basement membrane present on root dentin at day-8 of tooth development plays a critical inductive role in PDL differentiation. While the day6 ERS included in group A recominations most likely reconstitutes its own basement membrane in the process of cell attachment to the dentin specimen, it is apparent that any newly-synthesized basement membrane is incapable of initiating or supporting PDL development. In contrast, when the same epithelium is recombined in group B recombinations in the presence of day- 8 basement membrane, PDL formation is observed. Therefore, it is possible that the composition of the basement membrane retained on the root dentin specimens in group B recombinations is biologically unique. Studies by Lesot et al. ${ }^{29}$ and Thesleff et al. ${ }^{30}$ suggest that modulation of the molecular composition of basement membrane may be an important inductive signalling mechanism between juxtaposed epithelial and mesenchymal cells. Interestingly, in parallel studies employing immunohistochemical techniques, we have been unable to detect collagen type IV, a typical basement membrane constituent, in day-8 root basement membrane (unpublished observations). We postulate that tissue interactions which accompany early tooth development may influence the composition of the root-associated basement membrane; hence, timed alteration in basement membrane composition may represent a mechanism whereby root and PDL formation is controlled. As such, root development, like crown development, might be best considered a sequenced event determined and directed by prior and ongoing cell-matrix interactions.

An interesting finding in this study was the presence of a distinctive layer of darkly-staining cells along the root surface. Based on the experimental protocol employed and results from immunohistochemical staining, these cells occupy a histologic region where one would typically expect to detect epithelial root sheath cells. However, at the ultrastructural level, these cells were more fibroblastic than epithelial in nature, and also appeared engaged in matrix synthesis. As epithelial-mesenchymal transformation is a recognized feature of other developmental systems $\mathrm{s}^{31,32}$ and has been proposed as a potentially important feature of root development, ${ }^{12}$ the possibility that root sheath epithelium may undergo alteration in phenotype and participate directly in matrix synthesis should not be overlooked. Alternatively, epithelial root sheath cells may have quickly degenerated and been replaced by mesenchymal cells from the neighboring dental sac tissue.

In conclusion, this study suggests that periodontal attachment formation is determined by a complex interaction of dentin, extracellular matrix (i.e., basement membrane), epithelium, and mesenchyme. Elucidation of the cellular and molecular mechanisms involved in this process appears essential in our continuing attempts to fully understand and harness the developmental and regenerative powers of the periodontium.

\section{Acknowledgments}

The authors would like to thank Ms. Patty Indelicato for her assistance in the laboratory phase of this study and Ms. Lavinia Muncie and Ms. Chris Pearson for their technical assistance in electron microscopy. This study was suppor- 
tedc by NIDR grants DE07075 and DE07090. Dr. MacNeil was awarded the Balint Orban Memorial Award on presentation of this study at the 1990 Annual Meeting of The American Academy of Periodontology in Dallas, TX.

\section{REFERENCES}

1. Paynter KJ, Pudy G. A study of the structure, chemical nature, and development of cementum in the rat. Anat Rec 1958;131:233-251.

2. Owens PDA. Light and electron microscopic study of the early stages of root surface formation in molar teeth in the rat. Arch Oral Biol 1980;24:901-907.

3. Cho M-I, Garant PR. Ultrastructural evidence of directed cell migration during initial cementoblast differentiation in root formation. $J$ Periodont Res 1988;23:268-276.

4. Lester KS. The incorporation of epithelial cells by cementum. $J$ Ultrastruct Res 1969;27:63-87.

5. Lester KS. The unusual nature of root formation in molar teeth of the laboratory rat. $J$ Ultrastruct Res 1969;28:481-506.

6. Freeman E, Ten Cate AR. The development of the periodontuium. An electron microscopic study. J Periodontol 1971;42:387-395.

7. Ten Cate AR, Mills C, Solomon G. The development of the periodontium: a transplantation and autoradiographic study. Anat Rec 1971;170:365-380.

8. Ten Cate AR, Mills C. The development of the periodontium: The origin of alveolar bone. Anat Rec 1972;173:69-78.

9. Palmer RM, Lumsden AG. Development of periodontal ligament and alveolar bone in homografted recombinations of enamel organs and papillary, pulpal, and follicular mesenchyme in the mouse. Arch Oral Biol 1987;32:281-289.

10. Yoshikawa DK, Kollar EJ. Recombination experiments on the odontogenic roles of mouse dental papilla and dental sac tissues in ocular grafts. Arch Oral Biol 1981;12:745-753.

11. Ruch JV. Tooth morphogenesis and differentiation. In: Linde A, ed. Dentin and Dentinogenesis. Boca Raton, FL: CRC Press; 1984:47.

12. Thomas HF, Kollar EJ. Tissue interactions in normal murine root development. In: Davidovitch Z, ed. The Biological Mechanisms of Tooth Eruption and Root Resorption. Birmingham, AL: EBSCO Media; 1988:145-152.

13. Thomas HF, Kollar EJ. Differentiation of odontoblasts in grafted recombinations of murine epithelial root sheath and dental mesemchyme. Arch Oral Biol 1989;34:27-35.

14. Löe H, Waerhaug J. Experimental reimplantation of teeth in dogs and monkeys. Arch Oral Biol 1961;3:176-184.

15. Andreasen JO, Kristerson L. Evaluation of different types of autotransplanted connective tissues as potential periodontal ligament substitutes. Int J Oral Surg 1981;10:189-201.

16. Lindskog S, Blomlof L, Hammarstrom L. Evidence for a role of odontogenic epithelium in maintaining the periodontal ligament space. J Clin Periodontol 1988;15:371-373.

17. MacNeil RL, Thomas HF. Development of the murine periodontium.
I. Role of basement membrane in promoting mineralized tissue attachment to the developing root surface. J Periodontol 1993;64:95102.

18. Cohn SA. Development of the molar teeth in the albino mouse. Am $J$ Anat 1957;101:295-319.

19. Osman M, Ruch JV. Secretion of basal lamina by trypsin-isolated embryonic mouse molar epithelia cultured in vitro. Dev Biol 1980;75:467-470.

20. Sainte Marie G. A paraffin-embedding technique for studies employing immunofluorescence. J Histochem Cytochem 1962;10:250-255.

21. Johnson GD, Norueira Araujo, GM. A simple method to reduce fading of immunofluorescence during microscopy. J Immunol Methods 1981;43:349-50.

22. Kollar EJ. Epithelial-meschymal interactions in the mammalian integument. Tooth development as a model for instructive induction. In: Sawyer RH, J. Fallon J, eds. Epithelial-mesenchymal Interactions in Development. New York: Praeger Press; 1983:27-49.

23. Hall BK. Cellular interactions during cartilege and bone development. J Craniofac Genet Dev Biol 1991;11:238-250.

24. Merilees MJ, Scott L. Interaction of epithelial cells and fibroblasts in culture: Effect on glycosaminoglycan levels. Dev Biol 1980;76:396409.

25. Merilees MJ, Sodek J, Aubin JE. Effect of cells of epithelial rests of Malassez and endotheliail cells on synthesis of glycosaminoglycans by periodontal ligament fibroblasts in vitro. Dev Biol 1983;99:146153.

26. Slavkin HC. Towards a cellular and molecular understanding of periodontics. Cementogenesis revisited. J Periodontol 1976;47:259-255.

27. Slavkin HC, Bringas P Jr, Bessem C, et al. Hertwig's epithelial root sheath differentiation and initial cementum and bone formation during long term culture of mouse mandibular first molars using serumless, chemically-defined medium. J Periodont Res 1989;24:28-40.

28. Hynes RO. Integrins: A family of cell surface receptors. Cell 1987; 48:549-554.

29. Lesot $H$, Osman M, Ruch JV. Immunofluorescent localization of collagen, fibronectin, and laminin during terminal differentiation of odontoblasts. Dev Biol 1981;82:371-381.

30. Thesleff I, Barrach HJ, Foidart JM, Vaheri A, Pratt RM, Martin GR. Changes in the distribution of type IV collagen, laminin, proteoglycan and fibronectin during mouse tooth development. Dev Biol 1981;81:182-192.

31. Greenburg G, Hay ED. Epithelia suspended in collagen gels lose polarity and express characteristics of migrating mesenchymal cells. J Cell Biol 1982;95:333-339.

32. Nichols DH. Neural crest formation in the head of the mouse embryo as observed using a new histological technique. J Embryol Exp Morph 1981;64:105-120.

Send reprint requests to: Dr. R. Lamont MacNeil, Department of Periodontics/Prevention and Geriatrics, School of Dentistry, University of Michigan, Ann Arbor, MI 49100.

Accepted for publication October 13, 1992. 